\title{
BESKYTTELSE AV FREMTIDIGE INNTEKTER
}

Av professor ph.d Stig H. Solheim

Artikkelen problematiserer beskyttelse av fremtidige inntekter i relasjon til EMDs praksis om eiendomsvern etter EMK P1-1. Foranledningen er at problemstillingen har vart relevant for to nyere høyesterettssaker; HR-2017-2352-A (prostitusjons-saken) og HR-2018-1258-A (Gassled-saken). I prostitusjons-saken ble problematikken oversett, noe som har blitt kritisert. I Gassled-saken ble spфrsmålet problematisert, men Høyesterett valgte å ikke konkludere. Slik begrunnelsen er formulert, bidrar den likevel til en betydelig tvil om EMK P1-1 er anvendelig på fremtidige inntekter. Forfatteren mener det er vanskelig å forene Hoyesteretts argumentasjon i Gassled-saken med foreliggende konvensjonspraksis. Ettersom spфrsmålet også kan bli aktuelt i mange andre saker, er det viktig å få større klarhet om problemstillingen. I artikkelen beskrives flere ulike scenarier. Det pekes blant annet på at det finnes minst tre kategorier av fremtidige inntekter, som behandles noe ulikt av EMD.

Stig H. Solheim er født 1976, uteksaminert cand. jur. 2004, disputerte for graden ph.d. i rettsvitenskap 2010, og har fra 2015 vært professor ved Det juridiske fakultet, UiT, Norges arktiske universitet. Solheim har også vært konstituert lagdommer ved Hålogaland lagmannsrett i 2010-2011.

\section{$1 \quad$ Tema og aktualitet}

Beskyttelse av fremtidige inntekter har vært et tema for Høyesterett i to nyere saker. I HR-20172352-A (prostitusjons-saken) var det spørsmål om tap av fremtidige prostitusjonsinntekter hadde erstatningsrettslig vern. Flertallet (3-2) kom til at slike inntekter ikke var erstatningsrettslig beskyttet, blant annet fordi opptjening av inntektene forutsatte at en kriminell handling ville skje ettersom kjøp av seksuelle tjenester er kriminalisert. ${ }^{1}$ Både flertallet og mindretallet vurderte forholdet utelukkende etter tradisjonell norsk rett. Dommen er senere blitt kritisert, og det er reist spørsmål om ikke forholdet til Den europeiske menneskerettskonvensjon

\footnotetext{
${ }^{1}$ Se avsnitt 51.
} 
protokoll 1 artikkel 1 (EMK P1-1) burde ha vært vurdert. ${ }^{2}$ EMK P1-1 er gjort til en del av norsk rett ved lov 21. mai 1999 nr. 30 om styrking av menneskerettighetenes stilling i norsk rett (menneskerettsloven), jf. § 2. Ved motstrid går EMK P1-1 foran bestemmelser i annen lovgivning uten grunnlovs rang, jf. § 3. Når bestemmelsen anvendes i norske domstoler har Høyesterett uttalt at innholdet skal klarlegges gjennom bruk av «samme metode som EMD». ${ }^{3}$ Med «EMD» siktes det til Den europeiske menneskerettighetsdomstol i Strasbourg. Siden konvensjonspraksis er sentral i EMDs metode, vil konvensjonspraksis også være sentral for anvendelsen av EMK P1-1 i nasjonale domstoler. Det gjelder uavhengig av om avgjørelsene gjelder Norge eller andre land. ${ }^{4}$ Norske dommere kan videre være pliktig til å anvende konvensjonen av eget tiltak, selv om bestemmelsen ikke er påberopt. ${ }^{5}$ Det alene tilsier at det er interessant å få avklart om EMK P1-1 kunne fått betydning i prostitusjons-saken.

I HR-2018-1258-A (Gassled-saken) var det ett omstridt spørsmål om reduksjon av tariffer for gasstransport gjennom interessentskapet Gassled var å anse som et inngrep i eiendom etter EMK P1-1. ${ }^{6}$ Tariffreduksjonen var begrenset til fremtidige gasstransportavtaler, og gjaldt derfor i prinsippet bare fremtidige inntekter. Ved sakens behandling i Oslo tingrett og Borgarting lagmannsrett konkluderte begge instanser med at klagers manglende berettigede forventning til de fremtidige inntektene var avgjørende for at inngrepet falt utenfor det konvensjonsrettslige eiendomsvern. ${ }^{7}$ Spørsmålet var også sentralt ved sakens behandling i Høyesterett, men her valgte dommerne å holde spørsmålet åpent. ${ }^{8}$ Av premissene fremgår det imidlertid at Høyesterett ikke synes helt overbevist om at de aktuelle tariffinntektene var å anse som beskyttet eiendom, og det ble lagt til grunn at eierne av gassinfrastrukturen i alle fall ikke hadde noen berettiget forventning til inntekter utover hva det samlede regulatoriske regimet til gassinfrastrukturen ga grunnlag for. ${ }^{9}$ Dette poenget var videre sentralt for Høyesteretts endelige vurdering og konklusjon om at inngrepet uansett var proporsjonalt, og dermed ikke konvensjonsstridig. ${ }^{10}$

\footnotetext{
${ }^{2}$ Se Stig Eidissen, «Kortvarig tap av prostitusjonsinntekter og erstatningsrettslig vern - kommentar til HR-20172352-A», Lov og Rett x.x. (antatt, men ennå ikke publisert). NB: Note må oppdateres ved publikasjon.

${ }^{3}$ Rt. 2005 s. 883 avsnitt 45. Høyesterett har gjort noen reservasjoner i forhold til vektlegging av norske verdiprioriteringer, men det synes å ha fått minimal betydning i praksis.

${ }^{4}$ Se f.eks. Jens Edvin A. Skoghøy, Rett og Rettsanvendelse, Oslo 2018 s. 121.

${ }^{5}$ Se lov 17. juni 2005 nr. 90 om mekling og rettergang i sivile saker (tvisteloven) $§ \S 11-3$ til 11-5. Se også Grunnloven $\S 92$.

${ }^{6}$ Det gjøres oppmerksom på at forfatteren har hatt betenkningsoppdrag i anledning saken.

${ }^{7}$ Se henholdsvis TOSLO-2014-10957 punkt 7.4 og LB-2016-5707 punkt 4.2 og 4.3.

${ }^{8}$ Spørsmålet behandles i avsnittene 119-132. Høyesteretts åpne konklusjon følger av avsnitt 132.

${ }^{9}$ Se avsnitt 123.

${ }^{10} \mathrm{Se}$ avsnitt $138 \mathrm{flg}$.
} 
Hvorvidt norske myndigheter i relasjon til EMK står fritt til å gjøre inngrep i inntekter så lenge de er fremtidige, er av nokså stor praktisk betydning å få avklart. Det kan f.eks. få betydning for alle former for fremtidig priskontroll med varer og tjenester som bare gis virkning for nye kontrakter. Faller slike fremtidige inntekter i sin helhet utenfor konvensjonsvernet, vil norske domstoler være avskåret fra å foreta noen nærmere legitimitets- og proporsjonalitetskontroll med inngrepet. ${ }^{11}$ Siden priskontrollen bare gjelder fremover, og ikke krever noen avståelse av eiendom, vil inngrepet normalt heller ikke beskyttes av Grunnloven $\S \S 97$ og 105. ${ }^{12}$ Formålet med denne artikkelen er derfor å klargjøre i hvilken grad EMD anser fremtidige inntekter å falle inn under EMK P1-1, både fordi dette er den mest nærliggende eiendomsbeskyttelsen borgerne kan påberope seg, og fordi Høyesterett valgte å la spørsmålet stå åpent i Gassled-saken.

De retningslinjer EMD trekker opp for vurderingen må, som også Høyesterett har påpekt, legges til grunn når bestemmelsen er aktuell i norske domstoler. Av EMDs praksis fremgår det at anvendelsesområdet til EMK P1-1 bestemmes av to faktorer. ${ }^{13}$ For det første må det foreligge «eiendom» i konvensjonens forstand. For det andre må det foreligge et «inngrep» som staten svarer for. Dersom disse vilkårene ikke foreligger, er konvensjonen ikke anvendelig ratione materiae, og EMD skal da av eget tiltak avvise saken. ${ }^{14}$ At bestemmelsen er anvendelig må ikke forveksles med at den er krenket. Hvorvidt balansen mellom statens styringsbehov og individets beskyttelsesbehov er akseptabel, beror på en konkret vurdering av hvert enkelt tilfelle hvor særlig inngrepets proporsjonalitet står sentralt. Den konkrete rettferdiggjørelsen av inngrepet er ikke et tema for artikkelen. Her skal jeg bare søke å klargjøre når fremtidige inntekter anses å falle inn under EMK P1-1, slik at det overhodet blir nødvendig å foreta noen nærmere domstolskontroll.

Hvordan begrepet «inntekt» defineres er i denne sammenheng helt essensielt. I EMDs praksis kan det i alle fall skilles mellom tre ulike grupper av fremtidige inntekter. For det første kan det tales om fremtidige inntekter som knyttes til en bestemt fremtidig innsats eller ytelse, typisk lønnsinntekter. Se nærmere punkt 3. For det andre kan det tales om framtidige inntekter

\footnotetext{
${ }^{11}$ En legalitetskontroll er også en del av EMK-testen, men en tilsvarende kontroll vil uansett følge av Grl. § 113 , uten at vurderingene nødvendigvis alltid vil sammenfalle.

${ }^{12}$ I ekstreme tilfeller kan det selvfølgelig tenkes at Høyesterett vil skjære igjennom, men i normaltilfellet gir Grunnloven $\S \S 97$ og 105 ingen beskyttelse mot slike inngrep.

${ }^{13}$ For en kort oversikt over systematikken i EMK P1-1, se Stig H. Solheim, «Fra bot til bedring. Høyesteretts behandling av EMK P1-1», Rettsavklaring og Rettsutvikling Festskrift til Tore Schei, Oslo $2016 \mathrm{~s} .387-418$ på s. 388-390.

${ }^{14}$ Se EMK artikkel 35 nr. 3 bokstav a.
} 
som er knyttet til eiendomsretten til et underliggende eiendomsgode, typisk leieinntekter på fast eiendom. Se nærmere punkt 4. For det tredje kan det tales om fremtidige inntekter som knytter seg til fortsatt drift av en spesifikk virksomhet, typisk fremtidig salg av omsetningsvarer i en detaljhandel. Se nærmere punkt 5. I denne artikkelen skal alle tre kategoriene analyseres gjennom eksempler fra konvensjonspraksis. Selv om redegjørelsen ikke kan anses uttømmende med henhold til EMDs omfangsrike praksis, vil eksemplene illustrere hvordan EMD normalt behandler fremtidige inntekter i relasjon til eiendomsbeskyttelsen i EMK P1-1. Ved gjennomgangen av konvensjonspraksis vil jeg også forsøke å plassere hvor de to sakene Høyesterett nylig har behandlet, etter mitt syn, mest naturlig hører hjemme. Ettersom eiendomsspørsmålet alltid beror på en konkret helthetsvurdering, kan det selvsagt være delte meninger om akkurat det. Fremstillingen av praksis skal imidlertid være slik at leseren kan gjøre seg opp sin egen mening om spørsmålet, både i forhold til de to nevnte sakene, men også i forhold til andre saker hvor konvensjonens eiendomsvern kan være aktuell å påberope.

\section{Konvensjonens definisjon av eiendom og inngrep}

EMDs behandling av ulike fremtidige inntekter må særlig ses i sammenheng med konvensjonens eiendomsbegrep. I EMK P1-1 omtales eiendom både som «property» og «possessions». ${ }^{15}$ Det normale er å ta utgangspunktet $\mathrm{i}$ sistnevnte som anses å ha den videste betydning. ${ }^{16}$ Se f.eks. EMDs storkammeravgjørelse 13. desember 2000 Jan Malhous mot Den tsjekkiske republikk, hvor det ble uttalt:

«the Court recalls that, according to the established case-law of the Convention organs, 'possessions' can be 'existing possessions' [...] or assets, including claims, in respect of which the applicant can argue that he has at least a 'legitimate expectation' of obtaining effective enjoyment of a property right». ${ }^{17}$

Etter sikker konvensjonspraksis deles «possessions» altså inn i to hovedkategorier; eksisterende eiendom, og andre aktiva, inkludert krav, hvor klager har en berettiget forventning om å oppnå

\footnotetext{
${ }^{15}$ I den franske versjonen brukes «propriété» og «biens».

${ }^{16}$ Se Stig H. Solheim, Eiendomsbegrepet i Den europeiske menneskerettskonvensjon, Oslo 2010 s. 131-133.

${ }^{17}$ EMDs storkammeravgjørelse 13. desember 2000 Jan Malhous mot Den tsjekkiske republikk «the courts assessment» punkt d. Se tilsvarende formulering i f.eks. EMDs storkammerdom 30. august 2007 J.A. Pye (Oxford) LTD og J.A. Pye (Oxford) Land LTD mot Storbritannia avsnitt 61.
} 
effektiv eiendomsutnyttelse. ${ }^{18}$ Eksisterende eiendom skiller seg fra kategorien andre aktiva ved at man allerede kan utnytte eiendomsgodet. ${ }^{19}$ For andre aktiva, som hovedsakelig utgjør diverse typer krav, ligger den faktiske eiendomsutnyttelsen derimot inn i fremtiden. For at slike aktiva skal anses beskyttet, må de anses som såpass sikre at klager kan sies å ha en berettiget forventning om å komme i posisjon til faktisk utnyttelse. ${ }^{20}$ Det har blant annet sammenheng med at EMK P1-1 ikke skal gi en rett til å erverve ny eiendom, den skal bare beskytte posisjoner som allerede er etablert. ${ }^{21}$ EMD har da også eksplisitt uttalt at EMK P1-1 «does not, however, guarantee the right to acquire property.» ${ }^{22}$ Et viktig avgrensningskriterium for konvensjonens eiendomsbegrep, nettopp for å sikre at bestemmelsen begrenses til etablert eiendom, er at det aktuelle eiendomsgodet må ha tilstrekkelig grunnlag i nasjonal rett. ${ }^{23}$ I EMDs storkammerdom 28. september 2004 Kopecky mot Slovakia ble det f.eks. uttalt:

«the Court takes the view that where the proprietary interest is in the nature of a claim it may be regarded as an 'asset' only where it has a sufficient basis in national law, for example where there is settled case-law of the domestic courts confirming it.» ${ }^{24}$

Uttalelsen i denne saken gjelder bare eiendomsinteresser i form av krav, men kravet til tilstrekkelig grunnlag i nasjonal rett gjelder også for annen eiendom. ${ }^{25}$ Isolert sett fremstår uttalelsen som et nokså strengt avgrensingskriterium. Storkammerets uttalelse må imidlertid ses i sammenheng med den forutgående kammerbehandlingen i Kopecky, hvor flertallet hadde lagt til lagt til grunn at en "genuine dispute" eller et "arguable claim” kunne være nok til å ha berettiget forventning beskyttet under EMK P1-1. Selv om konvensjonspraksis hadde utviklet seg i retning av å anerkjenne også til dels omstridte krav, ønsket ikke storkammeret at grensene for eiendomsbegrepet skulle trekkes så løselig. Den ovenfor siterte uttalelsen er et direkte svar på dette, og gir ingen generell avklaring om hva EMD legger i kravet om at det nasjonale rettsgrunnlaget må være «sufficient». ${ }^{26}$ I saker hvor eiendomsspørsmålet fremstår som noe

\footnotetext{
${ }^{18}$ Se også Solheim 2010 s. 146-147.

${ }^{19}$ Det følger direkte av EMDs standardformulering av eiendomsbegrepet. Se også Solheim 2010 s. 194-195.

${ }^{20}$ Se Solheim 2010 s. 248 flg.

${ }^{21}$ Se f.eks. EMDs plenumsdom 13. juni 1979 Marckx mot Belgia avsnitt 50.

${ }^{22}$ Se f.eks. EMDs storkammerdom 28. september 2004 Kopecky mot Slovakia para 35.

${ }^{23}$ Se Solheim 2010 s. 169-181.

${ }^{24}$ Avsnitt 52.

${ }^{25}$ Se Solheim 2010 s. 171.

${ }^{26}$ Se nærmere Solheim 2010 s. 200-209 (eksisterende eiendom) og s. 248-283 (andre aktiva det er knyttet en berettiget forventning til).
} 
tvilsomt, som f.eks. i EMDs dom 5. januar 2000 Beyeler mot Italia, fremheves det imidlertid ofte at:

«The concept of possessions have an autonomous meaning and the issue that needs to be examined is whether the circumstances of the case, considered as a whole, conferred on the applicant title to a substantive interest protected by Article 1 of Protocol No. 1.» ${ }^{27}$

I praksis har det vist seg noe vanskelig å balansere et krav om tilstrekkelig grunnlag i nasjonal rett med en parallell doktrine om at eiendomsbegrepet har et autonomt innhold uavhengig av klassifiseringen i nasjonal rett. EMD synes å ha løst denne tilsynelatende motsetningen ved å stille krav om at klager i alle fall må identifisere et rettsstiftende element i nasjonal rett, samtidig som EMD forbeholder seg retten til selv å vurdere om dette er «sufficient». ${ }^{28}$ I Beyeler-saken var f.eks. klagers eiendomsrett til et verdifullt maleri avhengig av at staten ikke ut $\varnothing$ vde sin lovfestede forkjøpsrett. Forkjøpsretten var ikke bestridt som sådan. Saken gjaldt bare utøvelsen av denne. Men ettersom staten allerede hadde benyttet seg av forkjøpsretten, var det litt vanskelig for EMD å uten videre konstatere at klagers eiendom hadde «sufficient basis in national law». EMD kom likevel til at bestemmelsen var anvendelig, blant annet fordi klager i lang tid hadde hatt maleriet i sin besittelse, og at staten ved flere anledninger hadde behandlet ham som rette eier av maleriet. ${ }^{29}$ På dette grunnlaget konkluderte EMD med at sakens omstendigheter, helhetlig vurdert, hadde gitt klager rett til en substansiell interesse som var beskyttet av EMK P1-1. ${ }^{30}$

Etter dette kan en foreløpig oppsummering være at eiendomsbegrepets systematikk tilsier at fremtidige inntekter $i$ utgangspunktet ofte vil falle utenfor konvensjonens eiendomsvern. Skal fremtidige inntekter likevel falle innenfor eiendomsbegrepet, må kravet på inntekten enten være så godt etablert at det gir en berettiget forventning om at det vil oppfylles, eller så må inntekten knyttes til utnyttelsen av et eiendomsgode som allerede er etablert (eksisterende eiendom). I begge tilfeller må kravet på inntekten ha tilstrekkelig grunnlag i nasjonal rett. Til syvende og sist vil det avgjørende være om interessen, basert på en

\footnotetext{
${ }^{27}$ Se f.eks. EMDs dom 5. januar 2000 Beyeler mot Italia avsnitt 100. EMDs storkammerdom 30. november 2004 Öneryildiz mot Tyrkia avsnitt 124.

${ }^{28}$ Se Solheim 2010 s. 181.

${ }^{29}$ Se dommens avsnitt 104.

${ }^{30}$ Se mer utførlig, Solheim 2010 s. 309-336.
} 
helhetsvurdering av saken, anses å oppfylle kravene til beskyttet eiendom i EMK P1-1. Vurderingen av eiendomsbegrepets innhold vil kunne stille seg noe forskjellig alt etter hvilke typetilfeller EMD har til behandling. Denne systematikken synes derfor å ha vært avgjørende for at EMD i sin praksis har ansett det nødvendig å vurdere beskyttelse av fremtidige inntekter i minst tre ulike kategorier. Se nærmere om disse kategoriene i punktene 3,4 og 5.

Om det foreligger beskyttet eiendom er ikke alene avgjørende for om konvensjonens eiendomsbeskyttelse kommer til anvendelse. Beskyttelse av fremtidige inntekter kan i noen tilfeller også bero på om det er gjort et «inngrep» i disse. Det er viktig å være oppmerksom på at eiendomsvernet i EMK P1-1 er ikke begrenset til avståelsestilfeller, det dekker også alminnelige rådighetsbegrensinger, slik som f.eks. priskontroll. ${ }^{31} \mathrm{I}$ konvensjonspraksis omtales inngrep som «interference», og det skal generelt lite til for at vilkåret anses oppfylt. ${ }^{32}$ Det er normalt tilstrekkelig å påvise at statens handling har fått en $\emptyset$ konomisk betydning for klagers eiendom. ${ }^{33}$ Den $\varnothing$ konomiske betydningen må være over en viss minsteterskel, slik at problemet fremstår som reelt. ${ }^{34}$ I enkelte tilfeller kan EMD også pålegge statene en positiv forpliktelse til å beskytte eiendom. ${ }^{35}$ Det er imidlertid en vesensforskjell mellom å be myndighetene begrense sine egne direkte inngrep, og å pålegge dem en aktivitetsplikt for å beskytte privat eiendom. Terskelen for positive forpliktelser er derfor i utgangspunktet forholdvis høy. Dette får blant annet betydning for vurderingen av anvendeligheten til EMK P1-1 i prostitusjons-saken. Se nærmere i punkt 3.

Selv om drøftelsene av om det foreligger «eiendom», og om det er gjort «inngrep» $\mathrm{i}$ denne, er to prinsipielt uavhengige spørsmål, henger de nøye sammen. I EMDs praksis drøftes de også ofte under ett. ${ }^{36}$ Illustrerende for denne sammenhengen, er hvorvidt restriksjoner, og særlig potensielle restriksjoner, som forelå på tidspunktet for ervervelsen av en eiendom, skal anses som nye «inngrep» $\mathrm{i}$ eiendommen, eller om det bare er forhold som er med å definere hva det beskyttede eiendomsobjekt er. Dersom sistnevnte forståelse legges til grunn, vil potensielle restriksjoner som materialiserer seg på et senere tidspunkt ikke utgjøre reelle inngrep i

\footnotetext{
${ }^{31}$ Se f.eks. EMDs dom 12. juni 2012 Lindheim mfl. mot Norge avsnitt 77-78.

${ }^{32}$ Se Solheim 2010 s. 60-65.

${ }^{33}$ Økonomisk tap er imidlertid ikke et absolutt vilkår, se f.eks. EMDs storkammerdom 29. april 1999 Chassagnou mfl. mot Frankrike.

${ }^{34}$ EMK artikkel $35 \mathrm{nr} .3$ bokstav b angir at en sak kan avvises av EMD dersom klager «not suffered a significant disadvantage». Meningen med dette kriteriet er å sile bort bagatellmessige saker uten reell betydning for borgerne.

${ }^{35}$ Se nærmere Jon Fridrik Kjølbro, Den europaiske menneskerettighedskonventionn - for praktikere, København 2017 4. utg. s. 1203-1207.

${ }^{36}$ Se f.eks. EMDs dom 13. mars 2012 Malik mot Storbritannia. Saken er omtalt nærmere i hovedpunkt 5.
} 
eiendommen, og dermed falle utenfor EMK P1-1. I EMDs storkammerdom 30. august 2007 J.A. Pye (Oxford) LTD og J.A. Pye (Oxford) Land LTD mot Storbritannia argumenterte staten for at hevdsreglene, som var kjent og gjeldende på ervervstidspunktet, utgjorde en tilsvarende naturlig innskrenkning av klagers eiendomsrett. Når risikoen senere materialiserte seg, kunne ikke eieren hevde at anvendelsen av disse reglene var et inngrep staten svarte for. Storkammeret uttaler først at klagernes «possessions were necessarily limited by the various rules of statute and common law applicable to real estate.» ${ }^{37}$ Deretter gjør storkammeret følgende prinsipielle vurdering:

«It remains the case, however, that the applicant companies lost the beneficial ownership of 23 ha of agricultural land as a result of the operation of the 1925 and 1980 Acts. The Court finds inescapable the Chamber's conclusion that Article 1 of Protocol No. 1 is applicable.» ${ }^{38}$

Storkammeret legger til grunn at selv om den aktuelle hevdsregelen forelå, og var kjent på ervervstidspunktet, var EMK P1-1 utvilsomt anvendelig når hevdsregelen senere medførte at eiendomsretten gikk tapt. Potensielle restriksjoner som følger av det alminnelige regulatoriske regimet et eiendomsgode er underlagt, utgjør altså ingen begrensning av eiendomsobjektet som sådan. Når slike restriksjoner materialiserer seg på et senere tidspunkt, er de å anse som «inngrep»som må rettferdiggjøres innenfor rammene av EMK P1-1. Dette får blant annet betydning for Høyesteretts vurdering i Gassled-saken. Se nærmere i punktene 4 og 5.

\section{$3 \quad$ Lønn og andre ytelsesbaserte krav}

EMD har en rekke ganger uttalt at fremtidige inntekter som utgangspunkt ikke anses beskyttet av EMK P1-1. ${ }^{39}$ Spørsmålet kommer likevel ofte opp i praksis, og EMDs standardformulering for å vurdere dette er:

\footnotetext{
${ }^{37}$ Avsnitt 62.

${ }^{38}$ Avsnitt 63.

${ }^{39}$ Slik også Kjølbro 2017 s. 1201.
} 
«future income cannot be considered to constitute 'possessions' unless it has already been earned or is definitely payable". ${ }^{40}$

Begrepene «income» og «earned» indikerer at avgrensingskriteriet først og fremst er ment for fremtidige lønnsinntekter eller andre ytelsesbaserte krav. ${ }^{41}$ Det finnes betydelig EMD-praksis om slike krav. ${ }^{42}$ Selv om fremtidige lønnsinntekter i utgangspunktet faller utenfor konvensjonsvernet, kan det gjøres unntak. Det avgjørende er om grunnlaget for den fremtidige inntekten er noenlunde sikkert, altså om kravet anses å ha «sufficient basis» i nasjonal rett. ${ }^{43}$ Det var f.eks. spørsmålet i EMDs dom 8. november 2005 Kechko mot Ukraina. ${ }^{44}$ Klageren hevdet her at nektelse av å utbetale hans lovbaserte krav på lønnsøkning og bonus var i strid med EMK P1-1. Deler av lønnskravet ble avvist fordi det var foreldet etter nasjonal rett. Dette kravet kunne da heller ikke anses som eiendom etter konvensjonen. For det lønnskravet som fortsatt kunne gjøres gjeldende, hadde nasjonale domstoler likevel ikke gitt klager medhold. Ved sakens behandling i Strasbourg fremholdt EMD:

"The salary increase was payable with reference to a single, objective condition - the length of
time served by the applicant as a teacher. As the applicant fulfilled the 10 year condition, he can
be said to have had a reasonable expectation, if not a right, to receive the payment in question." ${ }^{45}$

Kravet på lønnsøkning var så konkret og håndfast at det fremstod som en rettighet. De nasjonale domstolenes anvendelse av ny lovgining, som med tilbakevirkende kraft medførte at kravet bortfalt, ble derfor ansett som en krenkelse av hans eiendomsrett. Når det gjaldt klagerens krav på bonus, ble det derimot fremhevet at "the payment of an excellent work bonus was dependent on more subjective factors, and required an assessment to be made of the applicant's

\footnotetext{
${ }^{40}$ Se f.eks. EMD storkammerdom 7. juni 2012 Centro Europa 7 S.R.L. og De Stafanio mot Italia avsnitt 172 og EMDs storkammerdom 11. januar 2007 Anheuser-Busch Inc. mot Portugal avsnitt 64.

${ }^{41}$ Se også Elena Sychenko, «Potenstial of the European Convention on Human Rights in the field of Wage Protection», E-Journal of International and Comparative Labour Studies, Vol. 6 No. 3 September-Oktober 2017.

${ }^{42}$ Se f.eks. EMDs avvisningsavgjørelse 13. desember 2016 Louw mot Sverige, EMDs storkammerdom 19. april 2007 Vilho Eskelinen mfl. mot Finland, EMDs dom 8. november 2005 Kechko mot Ukraina og EMDs dom 19. oktober 2000 Ambruosi mot Italia.

${ }^{43}$ Se likevel punkt 4 nedenfor. Noen ganger brukes også «enforcable claim» framfor «definitely payable», uten at det synes å utgjøre noen realitetsforskjell.

${ }^{44}$ EMDs dom 8. november 2005 Kechko mot Ukraina.

${ }^{45}$ Avsnitt 26.
} 
performance.”46 På grunn av skjønnet var det ikke tilstrekkelig håndhevbart, i alle fall ikke inntil det var truffet en innvilgende avgjørelse. Dette kravet falt derfor utenfor EMKs eiendomsbeskyttelse.

En annen sak, som illustrerer samme problemstilling, er EMDs storkammerdom 19. april 2007 Vilho Eskelinen mfl. mot Finland. Her hevdet enkelte polititjenestemenn at bortfall av individuelle lфnnstillegg var en krenkelse av EMK P1-1 sammenholdt med EMK artikkel 14. Lønnstilleggene var i utgangspunktet innvilget som en erstatning for at en tidligere kollektiv arbeidsavtale hadde opphevet en ordning med godtgjørelser for personer stasjonert i fjerntliggende strøk av landet. Grunnlaget for lønnstillegget var basert på en ny kollektiv arbeidsavtale. På grunn av intern omorganisering ble klagernes politidistrikt lagt ned og klagerne ble beordret til et nytt tjenestested. Det nye tjenestestedet ble ikke ansett som fjerntliggende, og klagerne fikk derfor ikke lenger utbetalt det aktuelle tillegget. Klagerne mottok heller ikke noen godtgjørelse for $\varnothing \mathrm{kt}$ pendlerdistanse. Ved vurderingen av om lønnstillegget kunne anses som beskyttet eiendom, viste EMD til den nye avtalen og konstaterte at vilkårene for tillegget ikke var oppfylt. Når det gjaldt manglende kompensasjon for $\emptyset \mathrm{kt}$ pendleravstand, ble det vist til at klagerne ikke kunne påvise at det fantes grunnlag for et slikt krav i finsk rett. Kravet manglet «sufficient basis» i nasjonal rett, og utgjorde da heller ingen beskyttet eiendomsinteresse i konvensjonens forstand.

Begge de refererte sakene viser at avgrensningskriteriet «future income» først og fremst passer for lønn og andre ytelsesbaserte krav. ${ }^{47}$ Det som må vurderes er om grunnlaget for de fremtidige inntektene fremstår som tilstrekkelig sikkert, noe som må følge av en tolkning av stiftelsesgrunnlaget for kravet. Hvor klageren ikke med en viss grad av sikkerhet kan vise at han etter stiftelsesgrunnlaget har en rett til fremtidig inntekt, vil heller ikke EMD godta at han har beskyttet eiendom i konvensjonens forstand. Dette er en naturlig tolkning av eiendomsbegrepet, da EMK P1-1 aldri har vært ment å inkludere en rett til å få eiendom. ${ }^{48}$ Normalt vil EMD også godta og legge til grunn nasjonale domstolers vurdering av kravets berettigelse etter nasjonal rett. Som blant annet Kecho-saken viser, finnes det noen unntak, uten at jeg trenger å gå nærmere inn på det i denne artikkelen. ${ }^{49}$

\footnotetext{
${ }^{46}$ Avsnitt 26.

${ }^{47}$ Ikke begrenset til lønn i snever forstand, men omfatter f.eks. også en advokats salærkrav, se EMDs dom 19. oktober 2000 Ambruosi mot Italia.

${ }^{48}$ Slik også Kjølbro 2017 s. 1201.

${ }^{49}$ For en mer utførlig drøftelse, se Solheim 2010 s. 263-281.
} 
Prostitusjons-saken hører etter mitt syn mest naturlig hjemme i denne kategorien EMDpraksis. Selv om seksuelle tjenester er ulovlig å kjøpe, er de ikke ulovlig å selge. Motytelsen fremstår da som lønn eller vederlag for tjenester. Ettersom de prostituertes inntekter i den konkrete saken berodde på tjenester som ennå ikke var ytt, kan kravet i utgangspunktet ikke anses som opptjent («earned») eller utvilsomt betalbart («definitely payable»). Som krav på fremtidige inntekter faller det derfor i utgangspunktet klart utenfor konvensjonens eiendomsbegrep. I den konkrete saken var imidlertid ikke kravet rettet mot innkreving av inntektene som sådan, men på substituttet for at de fremtidige inntektene man ikke fikk (erstatningskravet). Spørsmålet er om det endrer vurderingen. Stig Eidissen har antydet det i nylig publisert LoR-artikkel. ${ }^{50}$

Et erstatningskrav kan anses etablert allerede fra skadetidspunktet, og er da mulig å se på det som noe annet enn bare en løs fremtidig inntekt. ${ }^{51}$ EMD har i flere tilfeller akseptert at erstatningskrav, som klager ikke nådde fram med i nasjonale domstoler, likevel var tilstrekkelig etablert for å anse som eiendom etter konvensjonen. ${ }^{52}$ I disse sakene har inngrepet vært statlig avskjæring av det samme erstatningskravet som klagerne i alle fall på skadetidspunktet hadde en berettiget forventning om å nå fram med. Før Høyesterett avsa dom i prostitusjonssaken, var det ikke en helt urimelig antakelse at de prostituerte kunne vinne frem med sitt erstatningskrav for tap av fremtidige inntekter. ${ }^{53}$ På det grunnlaget kan det hevdes at Høyesterett burde vurdert om nektelsen av å anerkjenne erstatningskravet fremstod som legitimt og proporsjonalt ovenfor de prostituerte. Nå som det uttrykkelig er tatt stilling til at fremtidige prostitusjonsinntekter ikke kan anses erstatningsrettslig beskyttet, blir det vanskeligere å hevde at man har en berettiget forventning om å vinne fram med et slikt krav. Derfor vil i alle fall krav på erstatning for tap av fremtidige prostitusjonsinntekter for fremtiden klart falle utenfor konvensjonens eiendomsvern.

Eidissen nevner i sin artikkel også muligheten for at EMD alternativt kan komme til å se på anerkjennelse av erstatningskravet som en positiv forpliktelse for staten til å beskytte klagers arbeidsevne mot voldshandlinger fra andre borgere. ${ }^{54}$ Det er en interessant

\footnotetext{
${ }^{50}$ Stig Eidissen, «Kortvarig tap av prostitusjonsinntekter og erstatningsrettslig vern - kommentar til HR-20172352-A», Lov og Rett X.x. s. x.x (antatt, men ennå ikke publisert). NB: Note må oppdateres ved publikasjon. ${ }^{51}$ Slik også Stig Eidissen, «Kortvarig tap av prostitusjonsinntekter og erstatningsrettslig vern - kommentar til HR-2017-2352-A», Lov og Rett x.x. s. x.x (antatt, men ennå ikke publisert). NB: Note må oppdateres ved publikasjon.

${ }^{52}$ Se f.eks. EMDs dom 20. november 1995 Pressos Compania Naviera S.A. mfl. mot Belgia avsnitt 29-32, EMDs storkammerdom 6. oktober 2005 Draon mot Frankrike avsnitt 65-72 og EMDs storkammerdom 6. oktober 2005 Maurice mot Frankrike avsnitt 63-70.

${ }_{53}^{53}$ Det kreves imidlertid mer enn å ha en prosedabel sak, se Solheim 2010 s. 259-263.

${ }^{54}$ Stig Eidissen, «Kortvarig tap av prostitusjonsinntekter og erstatningsrettslig vern - kommentar til HR-20172352-A», Lov og Rett x.x s. x.X.. (antatt, men ennå ikke publisert). NB: Note må oppdateres ved publikasjon.
} 
innfallsvinkel som ikke kan utelukkes. Men ettersom terskelen for pålegge positive forpliktelser er forholdsvis høy, vil det etter mitt syn sannsynligvis ikke føre fram. ${ }^{55}$

\section{$4 \quad$ Inntekter knyttet til et underliggende eiendomsgode}

Fremtidige inntekter er selvsagt ikke begrenset til lønns- og ytelsesbaserte tilfeller. I EMDs praksis finnes det også en rekke eksempler på fremtidige inntekter i form av avkastning på et underliggende eiendomsgode. ${ }^{56}$ I disse sakene synes EMD gjennomgående å vurdere eiendomsspørsmålet ut fra om det underliggende eiendomsgodet $i$ seg selv kan anses som «possessions» i konvensjonens forstand. Også her kreves det at klager kan vise til et nasjonalrettslig grunnlag for stiftelsen av eiendomsretten. Men dersom eiendomsretten først anses etablert, blir retten til avkastningen eiendomsgodet genererer, inkludert fremtidige inntekter, ansett som en naturlig eierbeføyelse det eventuelt er gjort et konvensjonsstridig inngrep i. Det vurderes altså ikke isolert om den fremtidig avkastningen også er et eiendomsgode, og EMD bruker heller ikke formuleringen som er vanlig ved ytelsesbaserte inntekter («earned») eller «definietly payable»). I internasjonal rettslitteratur legges det også gjennomgående til grunn at «rent control» omfattes av EMK P1-1. ${ }^{57}$

Forskjellen mellom avkastning og lønns- og ytelsesbaserte krav har sammenheng med at det underliggende eiendomsgode i disse tilfellene anses som «eksisterende eiendom», hvor klager allerede er i posisjon til å utnytte eierbeføyelsene, herunder retten til å opptjene inntekter. Eiendomsretten til det underliggende godet er i seg selv et tilstrekkelig klart rettsgrunnlag for å gjøre krav på avkastningen, også i form av fremtidige inntekter. For eksisterende eiendom er det derfor ikke noe krav om at det må foreligge en berettiget forventning for at godet skal anses beskyttet. Eller sagt på en annen måte; den etablerte eiendomsretten til det underliggende eiendomsgodet skaper en implisitt berettiget forventning om å få den fremtidige avkastningen. Dette følger for så vidt også av helt alminnelig norsk tingsrettslig tenkning, og noe annet ville derfor egentlig vært ganske oppsiktsvekkende. ${ }^{58}$

\footnotetext{
${ }^{55}$ At terskelen for positive forpliktelser er forholdvis høy, påpekes også av Eidissen selv, se s. x.x. (noten må oppdateres ved publikasjon av artikkelen).

${ }^{56}$ Se f.eks. EMDs dom av 30. juli 2015 Zammit og Attard Cassar mot Malta, EMDs dom 12. juni 2012 Lindheim mfl. mot Norge, EMDs dom 26. september 2006 Fleri Soler og Camilleri mot Malta, EMDs storkammerdom 19. juni 2006 Hutten-Czapska mot Polen og EMDs plenumsdom 19. desember 1989 Mellacher mfl. mot Østerrike.

${ }^{57}$ Se f.eks. Harris, O’Boyle og Warbrick, Law of the European Convention on Human Rights, Oxford 20143. utgave s. 896 og Jacobs, White og Ovey, The European Convention on Human Rights, Oxford 2014 6. utgave s. 514.

${ }^{58}$ Se f.eks. Thor Falkanger og Aage Thor Falkanger, Tingsrett, Oslo 2016 8. utg. s. 40.
} 
Når eiendomsretten først anses etablert, gir den et tilstrekkelig nasjonalrettslig grunnlag også for fremtidige inntekter. I denne kategorien skiller EMD derfor ikke mellom avkastning etter allerede inngåtte kontrakter, og potensiell fremtidig avkastning i form av nye kontrakter. En sak som illustrerer dette er EMDs storkammerdom 19. juni 2006 Hutten-Czapska mot Polen. Her kom EMD til at myndighetenes begrensning av utleiepriser på boliger var i strid med EMK P1-1. Leieavtalene var i utgangspunktet ikke inngått frivillig mellom partene. Det var staten som påla eierne å leie ut leilighetene. Det var altså tale om inngrep i nye avtaler, ikke bare etablerte avtaler. Etter den polske lovgivningen var markedsleien sterkt begrenset, og det var heller ikke alternative muligheter til å få dekket kostnader til vedlikehold og oppussing av leilighetene. For klagerne innbar dette at de samlede utgiftene ved leieforholdet oversteg leieinntektene. Det var videre et vesentlig poeng at eierne, i tillegg til husleierestriksjonene, ikke kunne si opp leieavtalene og gjenvinne retten til å bruke leilighetene selv. Selv om EMD anerkjente de sterke boligsosiale hensynene som foranlediget inngrepet, innbar dette samlet sett at priskontrollen ikke tilfredsstilte proporsjonalitetskravet. EMD uttalte blant annet at disse restriksjonene «impaired the very essence of the applicant's right of property». ${ }^{59}$ Storkammeret gikk også langt i å kreve at staten justerte lovgivningen slik at utleierne kunne kreve "what might be considered a 'basic rent', 'economically justified rent' or 'decent profit'."60 Ikke på noe tidspunkt ble det problematisert at utleieinntektene, som åpenbart også var fremtidige, måtte anses som «future income» som falt utenfor konvensjonens eiendomsinngrep.

Et annet eksempel på at fremtidige inntekter i form av avkastning på et underliggende eiendomsgode anses beskyttet av konvensjonen, er EMDs dom 12. juni 2012 Lindheim mfl. mot Norge. I denne saken var det tale om avkastning på selve grunneiendommen i form av festeavgift. At nivået på festeavgiften i den opprinnelige og frivillig inngåtte kontrakten var akseptabel, var ikke et tema. Det klagerne bestred var festers lovfestede rett til å forlenge denne kontrakten på samme vilkår som før, når kontraktene utløp. De hevdet altså at en slik pålagt forlengelse av festeforholdet ville gi en fremtidig avkastning som var så lav at den stred mot eiendomsvernet i EMK P1-1. EMD la til grunn at klagerne hadde en berettiget forventning om at kontraktene ville utløpe som avtalt, selv om festeforhold allerede var underlagt en rekke restriksjoner. ${ }^{61}$ EMD ga som kjent også klagerne medhold i at priskontrollen var uproporsjonal. I denne relasjon er det interessante at det var ubestridt at EMK P1-1 kom til anvendelse. ${ }^{62}$ Det

\footnotetext{
${ }^{59}$ EMDs storkammerdom 19. juni 2006 Hutten-Czapska mot Polen avsnitt 203.

${ }^{60}$ Avsnitt 239, som viser til den polske konstitusjonsdomstolens anbefalinger, referert i avsnitt 136-141 i samme dom.

${ }^{61}$ Se avsnitt 133.

${ }^{62} \mathrm{Se}$ avsnitt 59.
} 
gjaldt selv om de fremtidige inntektene ikke bygget på en allerede inngått kontrakt, men kun på en pålagt kontraktsforlengelse som begrenset de fremtidige inntektene til eiendommen. Inngrepet, i form av pålagte kontraktsforlengelser til samme vilkår som før, grep altså inn i grunneiers muligheter til å oppnå en mer markedsmessig avkastning for perioden etter kontraktens utløp. EMD hadde likevel ingen betenkeligheter med å la konvensjonens eiendomsvern få anvendelse.

Det disse to sakene illustrerer er at avkastning på eksisterende eiendom, også i form av fremtidige inntekter, vurderes som en naturlig eierbeføyelse av EMD. Det vurderes ikke om inntektene isolert sett kan anses som eiendom i konvensjonens forstand, men om tiltaket som rammer inntektene utgjør et proporsjonalt inngrep i det underliggende eiendomsgode. EMD har gjennomgående vurdert begrensninger i eiers rett til å søke markedspris som et priskontrolltiltak som må rettferdiggjøres etter EMK P1-1. ${ }^{63}$ Det er også etter mitt syn fornuftig da priskontroll er en type inngrep hvor maktmisbruk presumptivt kan skje.

Selv om de fleste priskontrollsakene gjelder fast eiendom, synes denne innfallsvinkelen ikke å være begrenset til dette eiendomsgodet. I f.eks. EMDs dom 27. juni 2013 Kirovogradoblenergo, Pat mot Ukraina, klaget et kraftselskap på at de måtte selge strøm med $50 \%$ rabatt til landets dommere. Alle kraftselskap var gjennom lov pålagt å tilby dommere strøm til denne rabatten, og selv om det nok i utgangspunktet var lovgivers mening hadde ikke kraftselskapene noen reell mulighet for å søke dekning for dette tapet hos staten. EMD kom til at slik priskontroll utgjorde en krenkelse av EMK P1-1. I dommens avsnitt 37 uttaler EMD følgende:

«In the present case, the Judges Status Act unconditionally provided for a 50\% reduction in electricity payments for judges. That Act was not directed towards utility companies such as the applicant company but, as the domestic courts found [...], the applicant company was bound by it. Consequently, the applicant company was obliged to provide electricity free of charge to the above category of its clients. The Court considers that this obligation constituted an interference with its possessions."

\footnotetext{
${ }^{63}$ Se f.eks. EMDs dom av 30. juli 2015 Zammit og Attard Cassar mot Malta, EMDs dom 12. juni 2012 Lindheim mfl. mot Norge, EMDs dom 26. september 2006 Fleri Soler og Camilleri mot Malta, EMDs storkammerdom 19. juni 2006 Hutten-Czapska mot Polen og EMDs plenumsdom 19. desember 1989 Mellacher mfl. mot Østerrike.
} 
Det var altså også her tale om et pålagt kontraktsforhold som reduserte klagers mulighet til å søke fremtidig markedsavkastning på et gode de hadde en etablert eiendomsrett til (strømmen og nettverket). EMD tilkjennegir ingen tvil om at slik priskontroll er å anse som et inngrep i konvensjonsbeskyttet eiendom. Det gjaldt selv om den pålagte rabatten på $50 \%$ kun gjaldt en liten del av kundekretsen, og således ikke var av spesielt stor $\emptyset$ konomisk betydning for klager.

Etter mitt syn er det i utgangspunktet mest naturlig å plassere Gassled-saken i denne kategorien saker. De ankende parter hadde før tariffnedsettelsen kjøpt seg tungt inn i norsk gassinfrastruktur, hovedsakelig bestående av gassrør på norsk havbunn, diverse prosesseringsanlegg på norsk landjord og seks mottaksanlegg i Storbritannia, Frankrike, Belgia og Tyskland. Hvorvidt dette skal klassifiseres som fast eiendom eller noe annet kan sikkert diskuteres, men det er som nevnt ikke avgjørende. Det sentrale er at eierskapet til denne fysiske infrastrukturen var ubestridt. ${ }^{64}$ Det nasjonalrettslige grunnlaget for den underliggende eiendomsretten er dermed klar. Den viktigste eierbeføyelsen til gassinfrastrukturen er selvsagt retten til nåværende og fremtidige inntekter ved skiping av gass. At Gassled var pålagt å tilby sine tjenester til tredjemenn, og at prisen allerede var regulert gjennom den gamle tarifforskriften, endrer ikke dette. Når OED i den nye forskriften satte ned fortjenesteelementet i tariffen med $90 \%$ for kontrakter inngått etter 1. oktober 2016, var det åpenbart i den hensikt at avkastningen på gassinfrastrukturen skulle reguleres ytterligere. En slik priskontroll er etter mitt syn høyst sammenlignbar med andre priskontrollsaker i EMDs praksis.

Høyesterett gjorde imidlertid en annen vurdering. Først ble det uttalt at selv om staten har eiendomsretten til petroleumsressursene, og enerett til å forvalte ressursene og til å regulere utvinning og transport av norsk petroleum, er «eierandelene i Gassled eiendomsgoder på de ankende parters hender av en slik karakter at de er omfattet av P1-1». ${ }^{65}$ Høyesterett betviler altså ikke at eiendomsretten til gassinfrastrukturen som genererer inntektene er beskyttet av konvensjonen. I denne kategorien av saker vil det normalt innebære at man også har beskyttelse for de naturlig eierbeføyelsene som følger av den samme eiendomsretten, som inkluderer retten til avkastning. Høyesterett vurderer imidlertid dette annerledes og legger til grunn at:

«Den økonomiske interessen knyttet til å ha eierandeler i Gassled beror ikke først og fremst i selve anlegget. Verdien ligger i de tillatelsene Gassled har etter petroleumsloven § 1-3 og § 4-3

\footnotetext{
${ }^{64}$ Overdragelsene var også godkjent og registrert av OED.

${ }^{65}$ Avsnitt 120.
} 
til å ha og til å drive de fysiske installasjonene i konsesjonsperioden ut 2028, og som - med samtykke fra Olje- og energidepartementet etter $§ 10-12$ - ble overført fra de opprinnelige eierne til de nåværende ved salgene i årene 2010-2011. Den positive фkonomiske nåverdien av eierskapet i Gassled ligger reelt sett i forventningene om at tillatelsene gir grunnlag for fremtidige skipingsinntekter.» ${ }^{66}$

Høyesterett skiller altså mellom den økonomiske interessen som kan knyttes til de offentlige tillatelsene, og den økonomiske interessen som ligger $\mathrm{i}$ det å ha eiendomsretten til det underliggende eiendomsgodet tillatelsene er gitt for. Noen nærmere begrunnelse for hvorfor det er en rimelig vurdering gis ikke.

Etter mitt syn fremstår dette som en noe konstruert tilnærming til eiendomsspørsmålet. Er ikke inntektspotensialet til enhver eiendom avhengig av det reguleringsregimet det er underlagt? Utleieverdien til en bygård vil f.eks. avhenge om den er regulert til næring eller boliger (eller begge). Den positive $\emptyset$ konomiske nåverdien til bygården beregnes normalt etter hvilke forventninger det gjeldende reguleringsregimet gir til fremtidige leieinntekter. Ved overdragelse av eiendom er også normalordningen at kjøper trer inn i samme rettsposisjon som selgeren, også ovenfor det offentlige. Det fremstår derfor ikke som spesielt ekstraordinært at tillatelsene til å drive de fysiske gassinstallasjonene ble overført fra de opprinnelige til de nåværende eierne i Gassled i forbindelse med OEDs godkjenningen av selve transaksjonene. Strømlevrandøren i Kirovogradoblenergo, Pat mot Ukraina var garantert også avhengig av diverse offentlige tillatelser for å få operere i det ukrainske kraftmarkedet, uten at det synes å ha fătt betydning for EMDs bedømmelse av om priskontrollen utgjorde et inngrep i selskapets eierposisjon. Det er jo også eiendomsretten til det underliggende godet, og de naturlige eierbeføyelser det gir, som gjør at man overhodet snakker om nødvendigheten av ulike offentlige tillatelser.

På denne bakgrunn er det noe vanskelig å forstå hvordan Høyesterett kan se bort fra den underliggende eiendomsretten til gassinstallasjonene, selv om man legger til grunn at den $\emptyset$ konomiske interessen først og fremst er knyttet til de offentlige tillatelsene. Som jeg skal redegjøre nærmere for i punkt 5, behøver ikke dette å blir avgjørende for hvorvidt bestemmelsen er anvendelig eller ikke, men hvorvidt man anerkjenner at de fremtidige inntektene er knyttet til den underliggende eiendomsretten, kan ha stor betydning for bedømmelsen av inngrepets

\footnotetext{
66 Avsnitt 121.
} 
proporsjonalitet. Videre viser redegjørelsen i dette punktet at EMD gjennomgående legger til grunn at priskontroll med fremtidige inntekter fra et underliggende eiendomsgode faller inn under konvensjonens eiendomsvern. Det er en svakhet ved Gassled-dommen at Høyesterett ikke forsøker å forklare hvorfor EMDs praksis i priskontrollsaker ikke er viktigere for deres vurdering. Det er kanskje symptomatisk for saken, at den eneste priskontrolldommen Høyesterett velger å vise til, brukes helt feil. Se nærmere rett nedenfor.

\section{$5 \quad$ Inntekter knyttet til framtidig drift av en etablert virksomhet}

Fremtidige inntekter kan også knyttes til en tredje kategori saker i EMDs praksis. Det finnes en god del klager som knytter seg til tap av fremtidige inntekter ved at det gjøres inngrep i en etablert virksomhet. Denne kategorien inntekter er noe mer komplisert enn de som er nevnt ovenfor. Det har sammenheng med at EMD her synes å ha større utforinger ved å finne en rimelig balanse mellom beskyttelse av pågående virksomheter, og statens styringsbehov. Enhver myndighetsregulering som griper inn i virksomheters fremtidige inntektsmuligheter, kan nødvendigvis ikke anses som inngrep i beskyttet eiendom. I denne artikkelen lar det seg ikke gjøre å forfølge dette fra alle vinkler, men det skal særlig pekes på forholdet mellom beskyttelse av nåverdi og «goodwill», kontra løsere fremtidige omsetningsmuligheter. ${ }^{67}$ Det er den problemstillingen som er mest relevant for artikkelens tema og de norske sakene.

I tilfeller angående tilbaketrekking av konsesjoner eller tillatelser, har EMD gjennomgående lagt til grunn at «the economic interests connected with the underlying business» anses som eiendom. ${ }^{68}$ Det er ikke helt avklart om konsesjoner eller tillatelser $i$ seg selv kan anses som beskyttet eiendom, men det synes som en meget nærliggende konklusjon. ${ }^{69}$ I disse sakene fremheves det ofte at inngrepet får «adverse effects on the goodwill and value» til virksomheten..$^{70}$ At «goodwill» i seg selv anses beskyttet av EMK P1-1, er også lagt til grunn i rettslitteraturen. ${ }^{71}$ Det er her forholdet til fremtidige inntekter kommer inn. I noen tilfeller kan det være vanskelig å skille mellom påvirkning på nåverdi og «goodwill», og tap av fremtidige

\footnotetext{
${ }^{67}$ Se også Anish Bhasin, "Future Income Versus Goodwill under A1P1 - A Distinction without a Difference?", Judicial Review 2012 vol. 17:3 s. 226-235, DOI: 10.5235/108546812802915767.

${ }^{68}$ Se EMDs dom 13. mars 2012 Malik mot Storbritannia avsnitt 91, med videre henvisninger til blant annet EMDs dom 7. juli 1989 Tre Traktörer Aktiebolag mot Sverige og EMDs dom 18. februar 1991 Fredin mot Sverige.

${ }^{69}$ Det synes f.eks. lagt til grunn i EMDs dom 10. juli 2007 Bimer S.A. mot Moldova og EMDs dom 8. april 2008 Megadat.com SRL mot Moldova.

${ }^{70}$ Se EMDs dom 13. mars 2012 Malik mot Storbritannia avsnitt 91, med videre henvisning til Tre Traktörersaken.

${ }^{71}$ Se f.eks. Kjølbro 2017 s. 1196.
} 
omsetningsmuligheter. Særlig gjelder det hvor inntektene er knyttet til fremtidig innsats, slik at det blir avgrensingsproblemer mot kategorien lønn og andre ytelsesbaserte krav. ${ }^{72}$ EMDs dom 13. mars 2012 Malik mot Storbritannia kan illustrere dette. ${ }^{73}$ EMD uttaler her blant annet at:

\begin{abstract}
"The Court recalls that goodwill may be an element in the valuation of a professional practice or business engaged in commerce. Future income, on the other hand, is only a 'possession' once it has been earned, or an enforceable claim to it exists [...]. Where an applicant refers to the value of his business based upon the profits generated by the business, or the means of earning an income from the business, as 'goodwill', the Court has indicated that this reference is to be understood as a complaint in substance of loss of future income. The Court has previously found that this element of the complaint falls outside the scope of Article 1 of Protocol No. 1". ${ }^{74}$
\end{abstract}

Klager i saken var en lege som hadde inngått noe som ligner en norsk fastlegeavtale. Det ga blant annet rett til refusjon av visse leieutgifter og tilskudd for antall pasienter på legens liste. For å kunne inngå en slik avtale måtte man være oppført på en såkalt «performers list». Etter tilsyn med hans legepraksis ble han umiddelbart suspendert fra denne listen. Klager hevdet at suspensjonen utgjorde en krenkelse av hans rettigheter etter EMK P1-1. Staten hevdet på sin side at det her ikke forelå noe inngrep i klagers eiendom. EMD valgte i denne saken å se eiendoms- og inngrepsspørsmålet i sammenheng. EMD la vekt på at klager fortsatt fikk utbetalt 90 prosent av tilskuddet for pasientlisten. Videre kunne han selv klandres for ikke ha utfordret avgjørelsen om å nekte ham refusjon for leieinntektene, og han kunne ikke dokumentere at frafall fra listen skyldes suspensjonen. EMD anerkjente at avgjørelsen var egnet til å påvirke virksomhetens «goodwill», men ettersom det for legepraksiser var forbudt å ta betalt for denne, kunne heller ikke det tillegges vekt i den konkrete saken. Selv om det ikke fremgår klart, synes det som om EMD bygger på at det foreligger eiendom, men på grunn av de begrensede konsekvensene anses det ikke å være gjort noe inngrep i denne. Da foreligger det heller ingen krenkelse av EMK P1-1.

Selv om Høyesterett i Gassled-saken knyttet den økonomiske interessen til tillatelsene, og ikke eiendomsretten til gassinfrastrukturen, utelukker det altså ikke at priskontroll med

\footnotetext{
${ }^{72}$ Se punkt 3 .

${ }^{73}$ I samme retning, se Ian Edgar Liverpool Limited og Denimark Limited and 11 Others mot Storbritannia, avvisningsavgjørelser av 25. januar 2000 og 26. september 2000.

${ }^{74}$ Avsnitt 93.
} 
avkastningen i Gassled er et inngrep i de ankende parters eiendomsrett. Høyesterett la selv til grunn «at også disse tillatelsene er eiendomsgoder i den forstand uttrykket brukes i P1-1». ${ }^{75}$ Utfra konvensjonspraksis ville da den naturlige fremgangsmåte være å vurdere hvorvidt den nye tarifforskriften påvirket de ankende parters nåverdier, eller om det bare var generell samfunnskontroll som ville påvirke fremtidige omsetningsmuligheter. Høyesterett kunne for eksempel problematisert betydningen av at utstedte gjeldsobligasjoner fikk redusert sin «rating» etter at den nye tarifforkriften ble kjent i markedet. Videre kunne det vært gjort vurderinger av hvordan eventuell videresalgsverdi av andelene i Gassled ville bli påvirket av at fortjenesteelementet i tariffen ble redusert med $90 \%$ for nye kontrakter inngått mellom 1 . oktober 2016 og til utløpet av konsesjonsperioden i 2028. Eller om klagen «in substance» bare gjaldt løsere fremtidige omsetningsmuligheter som ikke reelt sett var egnet til å påvirke nåverdi og goodwill.

Høyesterett valgte imidlertid også her en annen tilnærming enn hva man kan forvente utfra EMDs praksis. Høyesterett mente at inntektene, som ble knyttet til tillatelsene, også måtte anses som berettiget utfra en totalvurdering av det reguleringsregime eiendomsgodet var underlagt. ${ }^{76}$ Avkastningen skilles altså først fra den underliggende eiendomsretten til gassinfrastrukturen ved at den egentlige verdien knyttes til tillatelsene. Deretter skilles det mellom inntekter fra tillatelsene som er berettigede, og inntekter man utfra en totalvurdering av reguleringsregimet ikke har noen berettiget forventning om å få. Sistnevnte indikeres det at faller helt utenfor konvensjonens eiendomsvern, selv om det nettopp er forhold ved reguleringsregimet som blir anført som problematisk. Dette harmonerer dårlig med storkammerets prinsipielle vurdering i J.A. Pye (Oxford) LTD og J.A. Pye (Oxford) Land LTD mot Storbritannia, hvor det ble lagt til grunn at også kjente potensielle restriksjoner i det generelle reguleringsregimet som gjaldt på ervervstidspunktet utvilsomt utgjør inngrep etter EMK P1-1. Se punkt 2 ovenfor.

Høyesteretts faglige forankring for denne innfallsvinkelen synes hovedsakelig å være henvisningen til EMDs dom 7. juni 2018 O'Sullivan McCarthy Mussel Development Ltd mot Irland. ${ }^{77}$ Saken gjaldt et midlertidig forbud mot «mussel seed fishing» som ble innført etter at irske myndigheter var blitt dømt for ikke å ha fulgt opp EU-rettslige miljøkrav. Fiskerne måtte ha en rekke godkjenninger og tillatelser for å delta i fisket, og selve fisketillatelsen ble utstedt

\footnotetext{
${ }^{75}$ Avsnitt 121.

${ }^{76}$ Avsnitt 123.

77 Avsnitt 123.
} 
årlig. ${ }^{78}$ Staten anførte at konvensjonen ikke var anvendelig da klagerne ikke hadde en berettiget forventning om å få utstedt fisketillatelser etter EU-dommen. ${ }^{79}$ EMD viste til at eiendomsspørsmålet beror på en konkret helhetsvurdering, og for lisenser og offentlige tillatelser ble det spesifikt sitert fra Malik-saken (gjengitt ovenfor) ${ }^{80}$ Deretter konkluderer EMD umiddelbart med: «In line with the above, the Court considers that the present case concerns a 'possession', namely the underlying aquaculture business of the applicant company». ${ }^{81} \mathrm{EMD}$ uttrykker altså aldri noen tvil om at det forelå eiendom i konvensjonens forstand. EMD er heller ikke i tvil om at det foreligger noe inngrep i denne eiendommen:

«As stated above [...], in assessing that interference the Court will bear in mind that the applicant company's activities were conducted subject to the conditions stipulated by the Minister each year when issuing the mussel seed authorisation, and that in 2008 the authorisation was not withdrawn or revoked but subject to temporary restriction.» ${ }^{82}$

EMD påpeker altså at forhold ved reguleringsregimet vil være en del av den videre vurderingen av saken, men det uttrykkes aldri noen tvil om at bestemmelsen er anvendelig. ${ }^{83}$ Det er også en åpenbar forskjell mellom å kreve å få utstedt en tillatelse som må fornyes årlig, og det og be om beskyttelse for rettigheter etter en tillatelse som allerede er gitt. Samlet sett er det derfor vanskelig å forstå hvorfor Høyesterett forsøker å forankre sitt standpunkt i denne dommen.

O'Sullivan-saken falt etter at Gassled-saken var tatt opp til doms. EMD-dommen var således ikke et tema under forhandlingene. Dette er selvsagt ikke til hinder for at Høyesterett kan bygge på dommen, men det kan ha fått betydning for hvor godt nyansene ved dommen ble belyst. Videre kan det nevnes at O'Sullivan-saken heller ikke var rettskraftig på domstidspunktet i Gassled-saken. Saken ble fors $ø$ kt brakt inn for storkammeret, og denne anken ble ikke avvist før 8. oktober 2018. Hvorvidt Høyesterett bør bygge sine begrunnelser på dommer som ikke er rettskraftig avgjort kan diskuteres, men ettersom dommen ble stående fikk det ikke noen avgjørende betydning i Gassled-saken.

\footnotetext{
78 Avsnitt 6.

${ }^{79}$ Avsnitt 72.

${ }^{80}$ Avsnitt 86-87.

${ }^{81}$ Avsnitt 88.

${ }^{82}$ Avsnitt 104.

${ }^{83}$ Se avsnitt 90-91.
} 
Høyesterett viser også til tre andre saker ved sin vurdering av inntektenes berettigelse i relasjon til reguleringsregimet. ${ }^{84}$ EMDs dom 6. februar 2018 Kristiana Ltd mot Litauen avsnitt 90-91, EMDs avvisningskjennelse 17. desember 2013 Crash 2000 OOD mot Bulgaria avsnitt 57 og EMDs dom 30. januar 2018 Cassar mot Malta avsnitt 44. Sakene har et variert faktum som jeg ikke skal gå nærmere inn på. Men det sakene har til felles, er at de alle gjaldt restriksjoner som eksisterte allerede da klagerne ervervet sine eiendommer. Det var altså ikke bare tale om potensielle restriksjoner som kunne blir realisert, men restriksjoner som allerede var en realitet. EMD har allerede avklart at potensielle restriksjoner ikke begrenser eiendomsgodet som sådan. EMD utelukker heller ikke at EMK P1-1 er anvendelig selv hvor restriksjoner var innført og kjent på ervervstidspunktet. Det gjelder spesielt i priskontrollsaker hvor klager har eiendomsretten til et underliggende eiendomsgode. Se ovenfor i punkt 4. I Cassar-saken avsnitt 44, som Høyesterett selv viser til, uttales det uttrykkelig at:

«the Court has not excluded that there might be particular cases where an applicant who bought a property in full knowledge that it was encumbered with restrictions may subsequently complain of an interference with his or her property rights, for example, where the said restrictions are alleged to be unlawful". ${ }^{85}$

EMD konkluderer deretter med at bestemmelsen er anvendelig, og det konstateres også krenkelse av konvensjonens eiendomsvern. ${ }^{86}$ Høyesterett viser altså til et sitat $\mathrm{i}$ en dom som underbygger den motsatte konklusjon av det Høyesterett selv har kommet til. Også i Kristianasaken konkluderer EMD med at bestemmelsen er anvendelig, men kommer deretter til at inngrepet er proporsjonalt. ${ }^{87}$ Den eneste saken som gir noe støtte til Høyesteretts syn er avvisningsavgjørelsen Crash 2000. Den sentrale årsaken til at tilfellet falt utenfor anvendelsesområdet til EMK P1-1 i denne saken, var at klagerne ikke kunne forvente å få utstedt byggetillatelser på et område som ble vernet ca. ti år før de kjøpte eiendommen. ${ }^{88}$ Saken gjaldt altså i realiteten manglende utøvelse av offentlig myndighet til fordel for klagerne i strid

\footnotetext{
${ }^{84}$ Se avsnitt 124 og 126.

${ }^{85}$ Avsnitt 44. Hjemmelsproblematikk var et hovedspørsmål i Gassled-saken.

${ }^{86}$ Avsnitt 49 og 62.

${ }^{87}$ Avsnitt 91 og 112-113.

${ }^{88}$ Avsnitt 57.
} 
med etablerte reguleringsplaner. Det er etter mitt syn lite sammenlignbart med krav om beskyttelse mot nye restriksjoner, selv om det generelle reguleringsregimet skulle hjemle muligheten for at nye restriksjoner kan bli innført. I Crash 2000 la EMD også betydelig vekt på at klagerne «has been able at all times to use the property on the same conditions as when it bought it" ${ }^{89}$ Det var åpenbart ikke tilfellet for de ankende parter i Gassled-saken hvor fortjenestelementet i tariffen ble redusert med $90 \%$ for kontrakter inngått etter 1. oktober 2016. Det må også bemerkes at dette er en avvisningssak, og at senere dommer, herunder Cassarsaken, har en mer nyansert tilnærming til spørsmålet.

Samlet sett mener jeg det kan stilles noen spørsmål ved kvaliteten av Høyesteretts vurdering av om EMK P1-1 var anvendelig i Gassled-saken. At konklusjonen til syvende og sist ble holdt åpen, endrer ikke dette. Det denne saken grunnleggende handler om, er hvorvidt staten har gjennomført en akseptabel priskontroll med inntekter fra eierskap i norsk gassinfrastruktur. I EMDs praksis, og i alle fall hvor det foreligger en klar og ubestridt eiendomsrett til et underliggende eiendomsgode, blir priskontrolltilfeller gjennomgående proporsjonalitetskontrollert. Bare den teoretiske muligheten for at staten kan falle for fristelsen til å prioritere egne interesser i overkant mye, burde være nok til at EMD, og norske domstoler, ivrer etter å foreta en slik kontroll. Det betyr ikke at domstolene må konkludere med krenkelse, men det betyr at man i alle fall bør tenke seg nøye om før man konkluderer med at bestemmelsen ikke kommer til anvendelse. I Gassled-saken er det særlig viktig ettersom utenlandske investeringsinteresser står i sterk kontrast til statens egne interesser. For det første var priskontrollen begrunnet med ressursforvaltningshensyn, som er ment å øke Norges inntekter fra sokkelen. Det er ikke noe galt i det, men interessemotsetningen til de som eier infrastrukturen blir meget tydelig. For det andre var Statoil (nå Equinor) en av de som solgte andeler i Gassled til de ankende parter. Prisingen av andelene ville åpenbart blitt en annen dersom endringen i tarifforskriften hadde vært varslet rett før salgsprosessen, og ikke som i denne saken, rett etter den siste overdragelsen var godkjent av OED. Timingen kan selvsagt ha vært tilfeldig, men den minste mistanke om det motsatte tilsier at man heller bør søke utvidet judisiell kontroll, heller enn å unngå det. Særlig når det tilsynelatende kan skje innenfor rammene til etablert praksis fra EMD. Høyesterett foretar heldigvis en viss proporsjonalitetskontroll i saken, men ved inngangen til denne vurderingen gjøres det en forutsetning om at «tariffreguleringen i 2013 er et inngrep i en berettiget forventning hos de

\footnotetext{
${ }^{89}$ Avsnitt 57.
} 
ankende parter». ${ }^{90}$ Spørsmålet er om det er mulig å gjøre en reell og balansert proporsjonalitetsvurdering når man allerede har gått langt i å konkludere med at forutsetningen ikke er tilstede? Jeg lar det spørsmålet stå åpent.

\section{Oppsummering og noen refleksjoner om subsidiaritet}

Analysen av EMDs praksis viser at beskyttelsen av fremtidige inntekter i stor grad avhenger av hvilket grunnlag inntekten bygger på. Er inntekten avhengig av fremtidig innsats eller ytelse, vil den som regel falle utenfor konvensjonenes eiendomsvern. Hovedbegrunnelsen for dette er at konvensjonen ikke skal kunne gi grunnlag for nye krav. EMK P1-1 beskytter bare etablerte interesser. Det motsatte utgangspunkt må tas for inntekter som bygger på et underliggende og etablert eiendomsgode. Her er inntektene å anse som avkastning av det etablerte eiendomsgode, og faller derfor normalt innenfor konvensjonens eiendomsvern. Det gjelder særlig ved inngrep i form av priskontroll. I Cassar-saken la EMD til grunn at selv priskontroll som allerede var innført og kjent på ervervstidspunktet kan stride mot konvensjonens eiendomsvern. Noe mer komplisert er det for inntekter som ikke direkte bygger på et underliggende og etablert eiendomsgode, men hvor inntektene er et resultat av en pågående virksomhet. EMD har i stor utstrekning også akseptert at inngrep i slike inntekter omfattes av konvensjonsvernet, men det gjelder ikke uten unntak. Avgjørende synes å være om det kan påvises konsekvenser for virksomhetens goodwill og nåverdi, og at det ikke bare er tale om tap av løsere fremtidige omsetningsmuligheter. EMD har særlig anvendt denne doktrinen ved tap og tilbaketrekning av konsesjoner og tillatelser, men har i O'Sullivan-saken lagt til grunn at konvensjonens eiendomsvern også kan komme til anvendelse hvor det er tale om å nekte fornyelse av nødvendige tillatelser.

Noen vil kanskje reagere på at EMD ikke tillegger kjennskap til potensielle, og til og med allerede innførte, restriksjoner mer vekt ved vurderingen av om det foreligger et inngrep i beskyttet eiendom. Her må det imidlertid presiseres at selv om EMD legger lite vekt på det ved spørsmålet om konvensjonen er anvendelig, er forutberegneligheten av inngrepet ofte sentralt ved vurderingen av proporsjonaliteten. ${ }^{91}$ Men ved å flytte relevansen av momentet til proporsjonalitetsvurderingen, kan konvensjonsstatene ikke unndra seg judisiell kontroll av ulike inngrep bare med en henvisning til at muligheten for et slikt inngrep fulgte av det

\footnotetext{
90 Avsnitt 134.

${ }^{91}$ Se f.eks. proporsjonalitetsvurderingen i Pye-saken og i O'Sullivan-saken.
} 
regulatoriske rammeverket som gjaldt på ervervstidspunktet. Selv om et inngrep er mulig å forutse, kan det ikke utelukkes at inngrepskompetansen likevel misbrukes.

Videre kan det spørres om hvorfor det er så viktig at EMK-jussen praktiseres helt korrekt i norske domstoler? Det mest åpenbare svaret er at vi folkerettslig har forpliktet oss til det, og at Stortinget har bestemt at EMK, med dets fulle folkerettslig innhold, skal gjelde som norsk lov. Det har imidlertid også en annen side. EMD har lenge uttalt at dens rolle er subsidiær, og nyere praksis synes dette å tillegges stadig større vekt. ${ }^{92}$ Tanken er at EMD ikke så lett skal kunne overprøve rimelige interesseavveininger som er gjort i konvensjonsstatene, enten av lovgiver selv, eller av nasjonale domstoler. Konvensjonsstatene skal tilkjennes en viss skjønnsmargin det ikke er naturlig at EMD overprøver. ${ }^{93}$ Som et resultat av dette har EMDs prøvelse av klagesakene i noen grad skiftet fra en materiell kontroll til en mer prosessuell kontroll. ${ }^{94}$ I tilfeller hvor EMD finner at EMK-rettighetene er rimelig vurdert og hensyntatt $\mathrm{i}$ den nasjonale prosessen, skal det mer til for at EMD overprøver resultatet enn hvor EMKrettighetene ikke er tilfredsstillende vurdert. ${ }^{95}$ Det er her viktigheten av å bygge på korrekte juridiske utgangspunkter kommer inn. Bærer en sak preg av at norske domstoler har søkt å unngå å foreta en reell vurdering av konvensjonsrettigheten, har EMD ingen grunn til å være tilbakeholden ved sin vurdering av saken. Det fikk vi f.eks. erfare i Lindheim, hvor EMD både påpekte at Høyesterett hadde oppstilt feil problemstilling for vurderingen av proporsjonaliteten, og påpekte at Høyesterett ikke i tilstrekkelig grad hadde hensyntatt utviklingen i nyere konvensjonspraksis. ${ }^{96}$ Det ble også lagt vekt på at lovgiver ikke hadde foretatt noen spesifikk analyse av om byrden mellom grunneierne og festerne var rimelig fordelt. ${ }^{97}$ EMD kunne derfor legitimere at de ut $\varnothing$ vde en sterkere prøvingsintensitet enn de ellers ville gjort. Forutsetningen for EMD skal utøve subsidiaritet, er altså at konvensjonsstatene ut $\varnothing v e r$ en tilsvarende primaritet. Det vil si at EMK-rettighetene må kunne håndheves korrekt og effektivt nasjonalt. Den sterke sammenhengen mellom subsidiaritet og primaritet, fremgår blant annet av Københavnerklæringen av mai $2018 .{ }^{98}$ Det er også pekt på denne sammenhengen i internasjonal

\footnotetext{
${ }^{92}$ Se nærmere Michael Reiertsen, The European Convention on Human Rights Article 13 - Past, Present and Future, Oslo 2017 (PhD-publikasjon).

${ }^{93}$ Denne skjønnsmarginen kan ikke uten videre overføres til forholdet mellom nasjonale domstoler og lovgiver.

${ }^{94}$ Se nærmere Silje Holten, «Har Den europeiske menneskerettsdomstolen endret bruken av skjønnsmarginen i retning av en mer prosessuell kontroll?», Jussens Venner 2018 nr. 2 s. 112-136.

${ }^{95}$ Se f.eks. EMDs storkammerdom 22. april 2013 Animal Defenders International mot Storbritannia.

${ }^{96}$ Lindheim avsnitt 135.

${ }^{97}$ Lindheim avsnitt 128.

98 https://www.echr.coe.int/Documents/Copenhagen_Declaration_ENG.pdf
} 
rettslitteratur. ${ }^{99}$ Staten kan altså gi seg selv større handlingsrom innenfor EMK, ved å sørge for at rettighetene ivaretas på en forsvarlig måte i nasjonal rett. Det vil sannsynligvis gi et mer effektivt vern for borgerne, og samtidig $\varnothing \mathrm{ke}$ sjansen for at avveininger mellom motstående interesser forblir et nasjonalt anliggende så lenge avveiningen fremstår som forsvarlig og bygger på referanser til relevant og oppdatert EMD-praksis. Staten har altså en egeninteresse, utover $\emptyset$ nsket om å være en forsvarlig rettsstat, i at EMK-anførsler prøves forsvarlig i norske domstoler.

${ }^{99}$ Se f.eks. Robert Spano, «The Future of the European Court of Human Rights - Subsidiarity, Process-Based Review and the Rule of Law», Human Rights Law Review, 2018 (18) s. 473-494, DOI: 10.1093/hrlr/ngy015 